\title{
Maternal ABVD chemotherapy for Hodgkin lymphoma in a dichorionic diamniotic pregnancy: a case report
}

\author{
Camille Cotteret $^{1}$, Yen-Vi Pham ${ }^{1}$, Ambroise Marcais², Marine Driessen ${ }^{3}$, Salvatore Cisternino ${ }^{1,4}$ and Joël Schlatter ${ }^{1 *}$
}

\begin{abstract}
Background: Hodgkin lymphoma $(\mathrm{HL})$ is the most common hematological malignancy during pregnancy. The firstline treatment for $\mathrm{HL}$ in pregnancy is the standard ABVD regimen without any drug and/or dose adjustment. However, data on chemotherapy during twin pregnancies are sparse, and a better understanding of the mechanisms involved in exposure to and the toxic effects of anticancer drugs in the fetuses is needed.

Case presentation: A 41-year-old dichorionic diamniotic pregnant patient was given ABVD treatment for HL at a gestational age of 28 weeks and 3 days. The patient received 2 cycles of chemotherapy with a 15-day therapeutic window including an actual $25 \mathrm{mg} / \mathrm{m}^{2}$ dose of doxorubicin per cycle. Unlike the female twin, the male twin presented four days after birth a left cardiac dysfunction. Doxorubicin cardiotoxicity in the male newborn was also supported by high blood levels of troponin. At one month of age, echocardiography findings were normal. We investigated literature data on physiological aspects of pregnancy that may influence doxorubicin pharmacokinetics, and pharmacodynamic and pharmacokinetic data on the use of doxorubicin in pregnancy. We detailed the role of the transporters in doxorubicin placenta distribution, and tried to understand why only one fetus was affected.

Conclusions: Fetal safety depends at least on maternal doxorubicin pharmacokinetics.Because of drug interactions (i.e. drug metabolism and drug transport), care should always be taken to avoid maternal pharmacokinetic variability. The toxic effects were discrepant between the dizygotic twins, suggesting additional fetus-specific pharmacokinetic/pharmacodynamic factors in doxorubicin toxicity.
\end{abstract}

Keywords: Twin dizygotic pregnancy, Hodgkin lymphoma, Doxorubicin, Cardiotoxicity, Fetus

\section{Background}

While the simultaneous occurrence of cancer and pregnancy is a rare medical event, hematological malignancies such as Hodgkin lymphoma (HL) occur in about $1 /$ 6000 pregnancies, which represent $3 \%$ of all HL patients [1-7]. In France, the number of new HL cases was estimated to be around 2000 per year, with $45 \%$ of them affecting women [8]. Staging the disease helps to determine the appropriate treatment. To treat advanced

\footnotetext{
* Correspondence: joel.schlatter@aphp.fr

'Hôpital universitaire Necker - Enfants malades, Pharmacie, F-75015 Paris, France

Full list of author information is available at the end of the article
}

stages (IIB, III and IV) during pregnancy, the ABVD regimen (doxorubicin, bleomycin, vinblastine and dacarbazine) is considered to be the best therapeutic choice, providing good overall survival and low toxicity for the fetus [9-12]. No consensus has been proposed to treat stage IA and IIA HL during pregnancy, but recommendation is to delay chemotherapy until delivery $[11,12]$. Therapeutic decision also depends on gestational age and fetal development. The management of ABVD toxicity requires consideration of physiological changes in pregnancy which affects drug pharmacokinetics. However, based on the limited clinical data about adaptation of chemotherapy during pregnancy, the standard ABVD

(c) The Author(s). 2020 Open Access This article is licensed under a Creative Commons Attribution 4.0 International License, which permits use, sharing, adaptation, distribution and reproduction in any medium or format, as long as you give appropriate credit to the original author(s) and the source, provide a link to the Creative Commons licence, and indicate if changes were made. The images or other third party material in this article are included in the article's Creative Commons licence, unless indicated otherwise in a credit line to the material. If material is not included in the article's Creative Commons licence and your intended use is not permitted by statutory regulation or exceeds the permitted use, you will need to obtain permission directly from the copyright holder. To view a copy of this licence, visit http://creativecommons.org/licenses/by/4.0/ The Creative Commons Public Domain Dedication waiver (http://creativecommons.org/publicdomain/zero/1.0/) applies to the data made available in this article, unless otherwise stated in a credit line to the data. 
protocol remains the current treatment for HL in pregnancy in North America and Europe [13, 14]. Small case series and retrospective studies in pregnancies treated for HL reported that doxorubicin was safe for the fetal heart when administered during the second and third trimester [9, 12, 15-17]. But they reported that doxorubicin in pregnancy could reduce the thickness of the left ventricular wall without causing heart defects or functional disorders [15].

In this article, we report a case of HL-complicated a twin dizygotic pregnancy in which ABVD administration was associated with reversible cardiac dysfunction in only one of the twins.

\section{Case presentation}

A 41-year-old woman pregnant with twins was admitted to our hematology department at a gestational age of 27 weeks for stage IIA HL. The disease history started with a vena cava syndrome associated with a right supraclavicular adenopathy up to $3 \mathrm{~cm}$. A thoracicabdominal-pelvic scan showed a compressive anterior mediastinal mass of $16 \mathrm{~cm}$ in diameter, and a lymph node biopsy confirmed the diagnosis of classic HL. The CRAT (French reference center about teratogenic agents) states that if the examination is necessary to ensure the best diagnostic/treatment of the patient, it can be performed with protective measures in a specialized department. Radiation levels were lower than the maximum recommended during pregnancy [18]. A course of corticosteroid (prednisone $80 \mathrm{mg} / \mathrm{d}$ and then $40 \mathrm{mg} / \mathrm{d}$ ) was started at the time of diagnosis. Maternal transthoracic echocardiography and electrocardiogram were normal. Fetuses' transabdominal echography at gestational ages of 18 weeks and 4 days, and 22 weeks and 3 days revealed normal morphologic examination. The heart was in normal position and there were four equilibrated cardiac cavities for each of twin. The intersection of the big vessels was normal. No abnormal cardiac rhythm was detectable. Cytological, urinary and hemostasis results were within the normal range at patient admission. A multidisciplinary team (hematologists and obstetricians) decided to start a chemotherapy regimen based on the ABVD protocol at a gestational age of 28 weeks and 3 days. The patient received 2 chemotherapy cycles on a 15-day outpatient basis (Table 1). During each outpatient hematology session, doxorubicin $25 \mathrm{mg} / \mathrm{m}^{2}$, bleomycin $10 \mathrm{mg} / \mathrm{m}^{2}$, vinblastine $6 \mathrm{mg} / \mathrm{m}^{2}$, dacarbazine 375 $\mathrm{mg} / \mathrm{m}^{2}$ (ABVD), and dexamethasone $10 \mathrm{mg}$ were given. The patient received medications such as ondansetron ( $8 \mathrm{mg}$ twice a day), prednisone ( $40 \mathrm{mg}$ per day from the diagnosis until 1 week after the first ABVD), enoxaparin (4000 UI twice a day), lansoprazole (30 mg once a day), and valaciclovir (500 mg once a day). Preterm premature rupture of membranes (PPROM) occurred on the same day as the completion of the second cycle of ABVD, corresponding to a gestational age of 32 weeks and 4 days. She was admitted in the maternity unit for surveillance and was given antibiotics by amoxicillin and steroids for fetal lung maturity. No sign of chorioamnionitis was found at that time (no contractions, no inflammatory sign in blood sample, no fetal tachycardia). She spontaneously went into labor at 33 weeks, and a cesarean section was performed given the prematurity and twin pregnancy. The latency period, from the PPROM to the delivery, seems to be shorter in twins compared with singleton pregnancies. Most studies report a median latency of less than $24 \mathrm{~h}$ [19].

The first twin born was a boy weighing $2030 \mathrm{~g}$ (50th percentile) and measuring $48 \mathrm{~cm}$. Head circumference was $31.5 \mathrm{~cm}$, Apgar score was $9 / 10 / 10$ and umbilical cord $\mathrm{pH}$ was 7.32 . The neonate presented normal respiration (45 breaths/min) and heart rate was 150 beats/ min. Blood count was normal with hemoglobin at $18 \mathrm{~g} /$ $\mathrm{dL}$ and platelets at $328,000 / \mathrm{mm}^{3}$. To avoid premature apnea, an intravenous loading and maintenance dose of caffeine $(5 \mathrm{mg} / \mathrm{kg} /$ day $)$ was given. The neonate breathed spontaneously with no apnea or bradycardia. Four days after delivery, an echocardiographic control examination

Table 1 ABVD protocol administered to twin pregnant women

\begin{tabular}{|c|c|c|c|c|c|c|c|}
\hline \multicolumn{2}{|c|}{ Patient: 41 years old } & \multicolumn{2}{|c|}{$\begin{array}{l}\text { Weight }(\mathrm{kg}): 85 \\
\text { Size }(\mathrm{cm}): 173 \\
\text { Body surface area }(\mathrm{m} 2): 1,99 \\
\text { Creatinine }(\mu \mathrm{mol} / \mathrm{L}): 58 \\
\text { Clearance }(\mathrm{mL} / \mathrm{min} \text {, Cockroft Gault): } 151\end{array}$} & \multicolumn{3}{|c|}{$\begin{array}{l}\text { Unit: Hematology } \\
\text { Cycle } 1 \mathrm{~J} 1=\text { November } 08,2017 \\
\text { Cycle duration: } 28 \text { days }\end{array}$} & \multirow[b]{2}{*}{ Timing } \\
\hline Drug & Dose of protocol & Total dose & Vehicle & Medical device & Route & Duration & \\
\hline Doxorubicin & $25 \mathrm{mg} / \mathrm{m} 2$ & $50 \mathrm{mg}$ & Glucose $5 \% 20 \mathrm{~mL}$ & Syringe & Intravenous & $5 \mathrm{~min}$ & $\mathrm{J1}$ and $\mathrm{J15}$ \\
\hline Bleomycin & $10 \mathrm{mg} / \mathrm{m} 2$ & $19.8 \mathrm{mg}$ & Sodium chloride $0.9 \% 20 \mathrm{~mL}$ & Syringe & Intravenous & $5 \mathrm{~min}$ & $\mathrm{~J} 1$ and $\mathrm{J} 15$ \\
\hline Vinblastine & $5 \mathrm{mg} / \mathrm{m} 2$ & $10 \mathrm{mg}$ & Sodium chloride $0.9 \% 20 \mathrm{~mL}$ & Bag & Intravenous & $5 \mathrm{~min}$ & $\mathrm{~J} 1$ and $\mathrm{J15}$ \\
\hline Dacarbazine & $375 \mathrm{mg} / \mathrm{m} 2$ & $750 \mathrm{mg}$ & Glucose $5 \% 250 \mathrm{~mL}$ & Bag & Infusion & $45 \mathrm{~min}$ & $\mathrm{~J} 1$ and $\mathrm{J} 15$ \\
\hline Ondansetron & $8 \mathrm{mg}$ & $8 \mathrm{mg}$ & No dilution & & Intravenous & $1 \mathrm{~min}$ & $\mathrm{~J} 1$ and $\mathrm{J} 15$ \\
\hline Dexamethasone & $10 \mathrm{mg}$ & $10 \mathrm{mg}$ & No dilution & & Intravenous & $5 \mathrm{~min}$ & $\mathrm{~J} 1$ and $\mathrm{J15}$ \\
\hline
\end{tabular}

Monitoring: hemogram, C-reactive protein (CRP), creatininemia, liver checkup 
showed a minor left cardiac dysfunction with preserved ejection fraction ( $\mathrm{HF} p \mathrm{EF})$ at $48 \%$, associated with a high concentration of troponin (Tn1: $103 \mathrm{ng} / \mathrm{L}$; reference: < $26 \mathrm{ng} / \mathrm{L}$ ). Cardiological advice was given and no therapy was initiated, but medical monitoring was started. When he was one-month-old, echocardiography findings were normal with a borderline LVEF at 50\% without pulmonary arterial hypertension. No troponin measurement was further performed. Following exclusive parenteral nutrition for 4 days, oral nutrition was progressively introduced with complete autonomy on day 17 . Neurological investigation was normal.

The second twin was a girl weighing $1785 \mathrm{~g}$ (25th percentile) and measuring $42 \mathrm{~cm}$ at birth. Head circumference was $32 \mathrm{~cm}$; Apgar score was 9/10/10 and umbilical cord $\mathrm{pH}$ was 7.32.Blood count was normal with hemoglobin at $19.2 \mathrm{~g} / \mathrm{dL}$ and platelets at $310,000 / \mathrm{mm}^{3}$. At birth, echocardiography results were normal, with a LVEF $>55 \%$. Neurological investigation was normal.

For the mother, ${ }^{18} \mathrm{~F}$-FDG PET and TDM scans were performed 20 days later and revealed complete metabolic remission. She was treated with 6 further ABVD cycles for consolidation.

\section{Discussion and conclusions}

We report here a case of a twin dizygotic pregnancy complicated by HL. A preterm rupture of membranes was diagnosed at 32 weeks and 4 days. ABVD administration was associated with reversible cardiac dysfunction in only one of the twins. Maggen and al. reported in a multicenter cohort study that $3 \%$ of 123 children born from mothers diagnosed with HL had a major congenital abnormality (syndactyly, atrial septal defect) at birth and $3 \%$ with minor abnormalities. They also reported that mothers who received prenatal chemotherapy experienced more obstetric complications (preterm contractions, preterm ruptures of membranes) [20]. In pregnancy, drug pharmacokinetics may be altered by maternal physiological changes. Thus, maternal drug distribution and/or elimination may be affected. Indeed, maternal serum albumin concentrations decrease from the pre-pregnancy value of $45.8 \mathrm{~g} / \mathrm{L}(7.6 \%)$, to $37.6 \mathrm{~g} / \mathrm{L}$ $(10 \%)$ at 34 weeks and $31.5 \mathrm{~g} / \mathrm{L}(17 \%)$ at 40 weeks of gestation $[21,22]$. The increase in intravascular and extravascular fluid partly explains the hypoalbuminemia observed during pregnancy, with a significant increase in the total body water [23]. Hypoalbuminemia can increase the free plasma fraction of drugs and alter their distribution in tissues. However, the low serum protein binding of doxorubicin ( 75\%) limits such variations in doxorubicin distribution.

The CYP2D6 and CYP3A4 activities increase up to $35 \%$ during the second and third trimesters [24]. The clearance of doxorubicin (CYP3A4 and CYP2D6 substrate) mainly involves liver metabolization and excretion via the bile duct [21]. However, some reports on doxorubicin clearance during pregnancy provide conflicting results about the effect of pregnancy on doxorubicin metabolism and variations in biliary excretion [22, 25-27]. Doxorubicin, a low molecular weight (544 $\mathrm{g} / \mathrm{mol}$ ) amphiphilic drug is also known as a substrate of the carbonyl reductases CBR1 and CBR3, which convert doxorubicin to doxorubicinol, an active and toxic metabolite, and other enzymes that produce some inactive metabolites (e.g. aglycones, glucuronides, and sulfates) [2830]. Doxorubicinol is more powerful than doxorubicin to compromise both systolic and diastolic cardiac functions [31]. Cardiotoxicity is reduced by decreasing circulating levels of doxorubicinol through the inhibition of CBR1 [32]. Doxorubicinol formation is under control of AKR1C3, CBR1, and CBR3 expressions [33]. To our knowledge, no data exist about impact of changes in their expression or activity during pregnancy. However, doxorubicinol quantity expressed as a ratio of its plasma concentrations, represented as an area-under-the-curve (AUC) (AUCdoxorubicinol/AUCdoxorubicin: $0.45 \pm$ 0.10 ; range: $0.33-0.61$ ) was not significantly different from that in non-pregnant women. It suggests that pregnancy does not affect metabolic pathway involved in the doxorubicinol formation [22]. Moreover, these studies also suggest that distribution volume and elimination (half-life) of doxorubicin are not statistically different in pregnant than in non-pregnant women [22, 27-29]. Placental capacity to transfer doxorubicin or pegylated liposomal doxorubicin from maternal blood to the fetal circulation was studied ex vivo with the human placental perfusion model [34]. This study showed a rapid decrease in doxorubicin concentration, with $30 \%$ doxorubicin remaining in the maternal circulation after $4 \mathrm{~h}$, and $12 \%$ doxorubicin in the fetal circulation. On the contrary, doxorubicin was not detected in the fetal circulation at any time point over $4 \mathrm{~h}$ of ex vivo placental perfusion with pegylated liposomal doxorubicin. These results suggest that pegylated liposomal doxorubicin did not cross the blood-placental barrier. While these reported data suggested that the maternal doxorubicin pharmacokinetic did not appear to differ during pregnancy, placental function and fetal factors were also possible sources of variability in the fetal exposure to doxorubicin or in its pharmacokinetics.

To further explain the low risk of fetal doxorubicin cardiotoxicity, the critical role of placental drug efflux transporters of the $\mathrm{ABC}$ superfamily in effectively controlling and limiting fetal drug/substrate exposure has been suggested $[35,36]$. Some studies demonstrated that $\mathrm{ABCB} 1$, also known as P-glycoprotein (P-gp), is critical for fetal protection by limiting exposure to substrates from the maternal circulation and removing them from 
the fetal circulation to the maternal circulation [37-39]. Table 2 summarizes the localization of selected doxorubicin carrier-mediated systems of the $\mathrm{ABC}$ superfamily, known to limit, at least at the human placenta, doxorubicin access to the fetal blood compartment. There are also known to affect the pharmacokinetics of doxorubicin through their polymorphisms. Therefore, the function of these drug transporters may be critical for fetal protection. P-gp and ABCG2 (BCRP) are expressed at the placenta and doxorubicin is well known as a dual P-gp and BCRP substrate. Detected in the syncytiotrophoblast microvilli bordering the maternal side of the human placenta, mean P-gp expression decreases from the 14th to the 40th weeks of gestation, suggesting a gradual decrease in fetal efficacy and protection [35, 36]. Although its clinical consequences are still poorly known, lowered P-gp expression/function at the placenta might increase the distribution of the drug substrate to the fetus, possibly intensifying its effects [37]. P-gp function could also be decreased by drug interactions with inhibitors such as amiodarone, cyclosporine or quinidine [44].

Intravenous ondansetron to prevent nausea and vomiting was prescribed off-label in our case report. Side effects including potential QT prolongation and torsade de pointes have been reported in the literature [45-47]. In the study conducted by Danielsson et al., data were analyzed from the Swedish medical birth register to identify 1349 infants born from women who had taken ondansetron in early pregnancy. There was a statistically increased risk for cardiovascular defects [48]. The authors hypothesized that potential QT interval prolongation by ondansetron could cause embryonic arrhythmias, suggesting that the drug should not be used off-label in early pregnancy. A recent study conducted by Fejzo et al. analyzed fetal outcome in pregnancies exposed to ondansetron in the United States. The results were similar with these findings [49].

Drug-drug interactions involving doxorubicin metabolism and/or transport should always be considered prior to initiation of doxorubicin treatment. The predictive role of P-gp polymorphism in doxorubicin fetal toxicity requires further clinical studies. Such genetic tests were not performed in our case.

In this case report, the maternal age of 41 years was a risk factor that should be considered. Advanced maternal age can contribute to multiple pregnancy complications such as spontaneous abortion, preeclampsia, gestational diabetes, fetal growth restriction, and stillbirth [50, 51]. Some studies have also reported an increased risk of septal defects in women who become pregnant at an advanced age $[52,53]$. Conversely, some studies have not found evidence of an association between maternal age and congenital heart disease [54-56].

One specificity of this case report is that twins reacted differently to the exposure. Even though the twins share the same uterus, the presence of two separate placentas brings a particular environmental influence for each twin $[57,58]$. The delivery of compounds, toxic or not, depends on the vascular system devoted to the individual twin [57]. In their study, Igbal and al. suggested that different expressions in the twins-genetic variation in the genes that encode for these drug transporters can significantly alter transporter function and may play a significant role in determining fetal sensitivity to maternal drugs [43]. In 2017, Hermel reported a case in which only one of the twins, born to a mother treated with dasatinib for chronic myeloid leukemia, had cardiac defects [59]. Hence, hypothesis could be placental discrepancy in doxorubicin distribution with a higher blood transfusion for the male twin.

The treatment of HL diagnosed during pregnancy is a major challenge for medical staff, who must propose the best treatment options while avoiding fetal toxicity. We

Table 2 ABC transporter gene polymorphisms of doxorubicin involved in human placenta [40-43]

\begin{tabular}{|c|c|c|c|c|}
\hline Transporter & $\begin{array}{l}\text { Syncytiotrophoblast } \\
\text { localization }\end{array}$ & Variant & $\begin{array}{l}\text { Modulation on disposition } \\
\text { of doxorubicin }\end{array}$ & $\begin{array}{l}\text { Modulation on cardiotoxicity } \\
\text { of doxorubicin }\end{array}$ \\
\hline \multirow[t]{2}{*}{$\begin{array}{l}\text { ABCB1 (P- } \\
\text { gp) }\end{array}$} & Apical & $1236 \mathrm{C}>\mathrm{T}$ & $\begin{array}{l}\text { Higher maximum plasma concentration, higher } \\
\text { AUC in T carriers }\end{array}$ & No data \\
\hline & & $\begin{array}{l}\text { Haplotype } 1236 \pi T 2677 \pi T \\
3435 T \pi\end{array}$ & Higher plasma concentrations in $\Pi T$ carriers & No data \\
\hline $\mathrm{ABCG} 2$ & Apical & $421 C>A$ & $\begin{array}{l}\text { No significant impact on doxorubicin } \\
\text { pharmacokinetics }\end{array}$ & No data \\
\hline $\begin{array}{l}\mathrm{ABCC1} \\
\text { (MRP1) }\end{array}$ & Apical & $2012 \mathrm{G}>\mathrm{T}$ & No data & $\begin{array}{l}\text { Higher acute cardiotoxicity in } \\
\mathrm{T} \text { carriers }\end{array}$ \\
\hline $\mathrm{ABCC2}$ & Apical & $3563 \mathrm{~T}>\mathrm{A} 4544 \mathrm{G}>\mathrm{A}$ & No data & $\begin{array}{l}\text { Higher acute cardiotoxicity in } \\
\text { A carriers }\end{array}$ \\
\hline ABCC5 & Basolateral & $1679 \mathrm{~T}>\mathrm{A}$ & Higher doxorubicinol exposure in $T$ carriers & No data \\
\hline
\end{tabular}


report one case of $\mathrm{HL}$ treated with an ABVD regimen during a dizygotic twin pregnancy, complicated by premature rupture of membranes and cardiotoxicity in one of the twins.

Even if no molecular mechanism could be hypothesized in our study, this case highlights the role of specific fetal factors that could confer variability in the pharmacokinetics and/or pharmaco/toxico-dynamics of doxorubicin.

\section{Abbreviations}

ABVD: Adriamycin/doxorubicin, bleomycin, vincristine, dacarbazine; ABC: ATPbinding cassette; AUC: Area under the curve; BCRP: Breast cancer resistance protein; ABCG2; HL: Hodgkin lymphoma; LVEF: Left ventricular ejection fraction; P-gp: P-glycoprotein; ABCB1

\section{Acknowledgements}

We thank Rasika Sowmyalakshmi for editing the English text.

\section{Authors' contributions}

$A M$ and $M D$ analyzed and interpreted the patient data regarding the hematological disease and twins data regarding clinical evaluation. CC, YVP SC and JS analyzed and discussed safety of doxorubicin treatment. CC, SC and JS were major contributor in writing manuscript. All authors read, revised and approved the final manuscript.

\section{Funding}

None.

\section{Availability of data and materials}

All data analyzed during this study are included in this published article.

\section{Ethics approval and consent to participate}

Not applicable. The local ethics committee ruled that no formal ethics approval was required in this particular case.

\section{Consent for publication}

The patient has given written consent for the publication of images and/or clinical details, on behalf of themselves and their children. A copy of the consent form is available for review by the Editor of this journal.

\section{Competing interests}

The authors declare that they have no competing interests.

\section{Author details}

${ }^{1}$ Hôpital universitaire Necker - Enfants malades, Pharmacie, F-75015 Paris, France. ${ }^{2}$ Hôpital universitaire Necker - Enfants malades, Hématologie adultes, F-75015 Paris, France. ${ }^{3}$ Hôpital universitaire Necker - Enfants malades, gynécologie-obstétrique, F-75015 Paris, France. ${ }^{4}$ Inserm UMR-S 1144, Team "Blood-brain barrier in brain pathophysiology and therapy", Université Paris Descartes, F-75006 Paris, France.

Received: 17 August 2019 Accepted: 7 April 2020

Published online: 19 April 2020

\section{References}

1. Haas JF. Pregnancy in association with a newly diagnosed cancer: a population-based epidemiologic assessment. Int J Cancer 1984;34: 229-235. https://doi.org/10.1002/ijc.2910340214.

2. Pinnix CC, Andraos TY, Milgrom S, Fanale MA. The Management of Lymphoma in the setting of pregnancy. Curr Hematol Malig Rep 2017;12(3): 251-256. https://doi.org/10.1007/s11899-017-0386-X.

3. Moshe Y, Bentur OS, Lishner M, Avivi I. The management of Hodgkin lymphomas in pregnancies. Eur J Haematol 2017;99(5):385-391. https://doi. org/10.1111/ejh.12956.

4. Pentheroudakis G, Pavlidis N. Cancer and pregnancy: poena magna, not anymore. Eur J Cancer 2006;42:126-140. https://doi.org/10.1016/j.ejca.2005. 10.014 .
5. Hurley TJ, McKinnell JV, Irani MS. Hematologic malignancies in pregnancy. Obstet Gynecol Clin N Am 2005;32:595-614. https://doi.org/10.1016/j.ogc. 2005.08.008

6. Brenner B, Avivi I, Lishner M. Haematological cancers in pregnancy. Lancet 2012;379:580-587. https://doi.org/10.1016/S0140-6736(11)61348-2.

7. Pavlidis N, Pentheroudakis G. The pregnant mother with breast cancer: diagnostic and therapeutic management. Cancer Treat Rev 2005;31:439_ 447. https://doi.org/10.1016/j.ctrv.2005.04.010.

8. Le Guyader-Peyrou S, Belot A, Maynadié M, Binder-Foucard F, Remontet L, Troussard X, Bossard N, Monnereau a; French network of cancer registries (Francim). Cancer incidence in France over the 1980-2012 period: hematological malignancies. Rev Epidemiol Sante Publique 2016;64(2):103112. https://doi.org/10.1016/j.respe.2015.12.017.

9. Avilés A, Nambo MJ, Neri N. Treatment of early stages Hodgkin lymphoma during pregnancy. Mediterr J Hematol Infect Dis 2018;10(1):e2018006. https://doi.org/10.4084/mjhid.2018.006.

10. Pereg D, Koren G, Lishner M. The treatment of Hodgkin and non-Hodgkin's lymphoma in pregnancy. Haematologica 2007;92:1230-1237. doi:10.3324/ haematol.11097.

11. Pinnix CC, Osborne EM, Chihama C, et al. Maternal and fetal outcome after therapy for Hodgkin and non-Hodgkin lymphoma diagnosed during pregnancy. JAMA Oncol 2016;3:1065-1069. doi:10.1001/jamaoncol.2016. 1396.

12. Eyre TA, Lau IJ, Mackillop L, Collins GP. Management and controversies of classical Hodgkin lymphoma in pregnancy. Br J Haematol 2015;169:513-630. https://doi.org/10.1111/bjh.13327.

13. Peccatori FA, Azim HA Jr, Orecchia R, Hoekstra HJ, Pavlidis N, Kesic V, Pentheroudakis G. ESMO Guidelines Working Group. Cancer, pregnancy and fertility: ESMO Clinical Practice Guidelines for diagnosis, treatment and follow-up. Ann Oncol 2013;24 Suppl 6:vi160-vi170. https://doi.org/10.1093/ annonc/mdt199.

14. Bachanova V, Connors JM. Hodgkin lymphoma in pregnancy. Curr Hematol Malig Rep 2013;8(3):211-217. https://doi.org/10.1007/s11899-013-0163-4.

15. Framarino-Dei-Malatesta M, Sammartino P, Napoli A. Does anthracyclinebased chemotherapy in pregnant women with cancer offer safe cardiac and neurodevelopmental outcomes for the developing fetus? BMC Cancer 2017;17(1):777. https://doi.org/10.1186/s12885-017-3772-9.

16. Iriyama N, Horikoshi A, Tanaka T, Hirabayashi Y, Kodaira H, Hatta Y, Takeuchi J. Successful treatment of Hodgkin lymphoma in second trimester of pregnancy: feasibility of ABVD regimen. Int J Hematol 2011;94(1):104-107. https://doi.org/10.1007/s12185-011-0876-X

17. De Sanctis V, Filippone FR, Alfò M, Muni R, Cavalieri E, Pulsoni A, Annechini G, Valeriani M, Osti MF, Minniti G, Enrici RM. Impact of different treatment approaches on pregnancy outcomes in 99 women treated for Hodgkin lymphoma. Int J Radiat Oncol Biol Phys 2012;84(3):755-761.https://doi.org/ 10.1016/j.jijrobp.2011.12.066

18. Centre de Référence sur les Agents Tératogènes. Hôpital Trousseau (Paris, France): Radiations ionisantes - Grossesse. https://lecrat.fr/spip.php?page= article\&id_article=254. Accessed 29 Jan 2020.

19. Sela HY, Simpson LL. Preterm premature rupture of membranes complicating twin pregnancy: management considerations. Clin Obstet Gynecol 2011;54:321-329. https://doi.org/10.1016/j.jogc.2019.06.016.

20. Maggen C, Dierickx D, Lugtenburg P, Laenen A, Cardonick E, Smakov R, Bellido M, Cabrera-Garcia A, Gziri MM, Halaska MJ, Ottevanger PB, Van Calsteren K, O'Laughlin A, Polushkina E, Van Dam L, Avivi I, Vandenberghe P, Woei-A-Jin FJSH, Amant F. International Network on Cancer, Infertility and Pregnancy. Obstetric and maternal outcomes in patients diagnosed with Hodgkin lymphoma during pregnancy: a multicentre, retrospective, cohort study. Lancet Haematol 2019; 6(11):e551-e561. https:/doi.org/10.1016/S2352-3026(19)30195-4.

21. Abduljalil K, Furness $P$, Johnson TN, Rostami-Hodjegan A, Soltani H. Anatomical, physiological and metabolic changes with gestational age during normal pregnancy: a database for parameters required in physiologically based pharmacokinetic modelling. Clin Pharmacokinet 2012; 51(6):365-396. https://doi.org/10.2165/11597440-000000000-00000.

22. Ryu RJ, Eyal S, Kaplan HG, Akbarzadeh A, Hays K, Puhl K, Easterling TR, Berg SL, Scorsone KA, Feldman EM, Umans JG, Miodovnik M, Hebert MF. Pharmacokinetics of doxorubicin in pregnant women. Cancer Chemother Pharmacol 2014:73(4):789-797. https://doi.org/10.1007/s00280-014-2406-z.

23. Lukaski H, Skiers W, Nielsen E, Hall C. Total body water in pregnancy: assessment by using bioelectrical impedance. Am J Clin Nutr 1994:59:578585. https://doi.org/10.1093/ajcn/59.3.578. 
24. Tracy TS, Venkataramanan R, Glover DD, Caritis SN, National Institute for child health and human development network of maternal-fetal-medicine units. Temporal changes in drug metabolism (CYP1A2, CYP2D6 and CYP3A activity) during pregnancy. Am J Obstet Gynecol 2005;192(2):633-639. https://doi.org/10.1016/j.ajog.2004.08.030.

25. Piscitelli SC, Rodvold KA, Rushing DA, Tewksbury DA. Pharmacokinetics and pharmacodynamics of doxorubicin in patients with small cell lung cancer. Clin Pharmacol Ther 1993:53:555-561. https://doi.org/10.1038/clpt.1993.69.

26. Rodvold KA, Rushing DA, Tewksbury DA. Doxorubicin clearance in the obese. J Clin Oncol $1988 ; 6: 1321-1327$. DOl: 10.1200/JCO.1988.6.8.1321.

27. Jacquet JM, Bressolle F, Galtier M, et al. Doxorubicin and doxorubicinol: intra and inter-individual variations of pharmacokinetic parameters. Cancer Chemother Pharmacol 1990;39:507. https://doi.org/10.1007/BF00685716.

28. Bains OS, Karkling MJ, Grigliatti TA, Reid RE, Riggs KW. Two nonsynonymous single nucleotide polymorphisms of human carbonyl reductase 1 demonstrate reduced in vitro metabolism of daunorubicin and doxorubicin Drug Metab Dispos 2009;37(5):1107-1114. https://doi.org/10.1124/dmd.108. 024711

29. Bains OS, Karkling MJ, Lubieniecka JM, Grigliatti TA, Reid RE, Riggs KW. Naturally occurring variants of human CBR3 alter anthracycline in vitro metabolism. J Pharmacol Exp Ther 2010;332(3):755-763. https://doi.org/10. 1124/jpet.109.160614.

30. Kassner N, Huse K, Martin HJ, Gödtel-Armbrust U, Metzger A, Meineke I, Brockmöller J, Klein K, Zanger UM, Maser E, Wojnowski L. Carbonyl reductase 1 is a predominant doxorubicin reductase in the human liver Drug Metab Dispos 2008;36(10):2113-2120. https://doi.org/10.1124/dmd.108. 022251

31. Forrest GL, Gonzalez B, Tseng W, Li X, Mann J. Human carbonyl reductase overexpression in the heart advances the development of doxorubicininduced cardiotoxicity in transgenic mice. Cancer Res. 2000;60(18):5158-64.

32. Olson LE, Bedja D, Alvey SJ, Cardounel AJ, Gabrielson KL, Reeves RH. Protection from doxorubicin-induced cardiac toxicity in mice with a null allele of carbonyl reductase 1. Cancer Res. 2003;63(20):6602-6.

33. Thorn CF, Oshiro C, Marsh S, Hernandez-Boussard T, McLeod H, Klein TE, Altman RB. Doxorubicin pathways: pharmacodynamics and adverse effects. Pharmacogenet Genomics 2011;21(7):440-446. DOI: 10.1097/FPC. Ob013e32833ffb56

34. Soininen SK, Repo JK, Karttunen V, Auriola S, Vähäkangas KH, Ruponen M. Human placental cell and tissue uptake of doxorubicin and its liposomal formulations. Toxicol Lett 2015;239(2):108-114. https://doi.org/10.1016/j. toxlet.2015.09.011.

35. MacFarland A, Abramovich DR, Ewen SW, Pearson CK. Stage-specific distribution of P-glycoprotein in first-trimester and full-term human placenta. Histochem J 1994;26(5):417-423. https://doi.org/10.1007/ BF00160054.

36. Gil S, Saura R, Forestier F, Farinotti R. P-glycoprotein expression of the human placenta during pregnancy. Placenta 2005;26(2-3):268-270. https:// doi.org/10.1016/j.placenta.2004.05.013.

37. Ceckova-Novotna M, Pavek P, Staud F. P-glycoprotein in the placenta: expression, localization, regulation and function. Reprod Toxicol 2006;22(3): 400-410. https://doi.org/10.1016/j.reprotox.2006.01.007.

38. Nanayakkara AK, Follit CA, Chen G, Williams NS, Vogel PD, Wise JG. Targeted inhibitors of P-glycoprotein increase chemotherapeutic-induced mortality of multidrug resistant tumor cells. Sci Rep 2018;8(1):967. https://doi.org/10. 1038/s41598-018-19325-x.

39. Pavek P, Staud F, Fendrich Z, Slenarova H, Libra A, Novotna M, et al. Examination of the functional activity of P-glycoprotein in the rat placental barrier using rhodamine 123. J Pharmacol Exp Ther 2003;305(3):1239-1250. https://doi.org/10.1124/jpet.102.048470.

40. Walker N, Filis P, Soffientini U, Bellingham M, O'Shaughnessy PJ, Fowler PA Placental transporter localization and expression in the human: the importance of species, sex, and gestational age differences. Biol Reprod 2017;96(4):733-742. https://doi.org/10.1093/biolre/iox012.

41. Joshi AA, Vaidya SS, St-Pierre MV, Mikheev AM, Desino KE, Nyandege AN Audus KL, Unadkat JD, Gerk PM. Placental ABC transporters: biological impact and pharmaceutical significance. Pharm Res 2016:33(12):2847-2878. https://doi.org/10.1007/s11095-016-2028-8.

42. Staud F, Cerveny L, Ceckova M. Pharmacotherapy in pregnancy; effect of $A B C$ and SLC transporters on drug transport across the placenta and fetal drug exposure. J Drug Target 2012;20(9):736-763. https://doi.org/10.3109/ 1061186X.2012.716847.
43. Iqbal M, Audette MC, Petropoulos S, Gibb W, Matthews SG. Placental drug transporters and their role in fetal protection. Placenta 2012;33(3):137-142. https://doi.org/10.1016/j.placenta.2012.01.008.

44. Pavek P, Fendrich Z, Staud F, Malakova J, Brozmanova H, Laznicek M, et al. Influence of P-glycoprotein on the transplacental passage of cyclosporine. J Pharm Sci 2001;90(10):1583-1592. https://doi.org/10.1002/jps.1108.

45. Koren G. Scary science: Ondansetron safety in pregnancy-two opposing results from the same Danish registry. Ther Drug Monit 2014;36: 1-2. doi: 10.1097/FTD.0000000000000020.

46. Li K, Vo K, Lee BK, Addo N, Coralic Z. Effect of a single dose of i.v. ondansetron on QTc interval in emergency department patients. Am J Health Syst Pharm 2018;75(5):276-282. https://doi.org/10.2146/ajhp161070.

47. Lee DY, Trinh T, Roy SK. Torsades de Pointes after Ondansetron Infusion in 2 Patients. Tex Heart Inst J 2017;44(5):366-369. https://doi.org/10.14503/THIJ16-6040.

48. Danielsson B, Wikner BN, Källén B. Use of ondansetron during pregnancy and congenital malformations in the infant. Reprod Toxicol 2014;50:134137. https://doi.org/10.1016/j.reprotox.2014.10.017.

49. Fejzo MS, MacGibbon KW, Mullin PM. Ondansetron in pregnancy and risk of adverse fetal outcomes in the United States. Reprod Toxicol 2016;62:87-91. https://doi.org/10.1016/j.reprotox.2016.04.027.

50. Salem Yaniv S, Levy A, Wiznitzer A, Holcberg G, Mazor M, Sheiner E. A significant linear association exists between advanced maternal age and adverse perinatal outcome. Arch Gynecol Obstet 2011:283(4):755-759. https://doi.org/10.1007/s00404-010-1459-4.

51. Laopaiboon M, Lumbiganon P, Intarut N, Mori R, Ganchimeg T, Vogel JP, Souza JP, Gülmezoglu AM. WHO Multicountry Survey on Maternal Newborn Health Research Network. Advanced maternal age and pregnancy outcomes: a multicountry assessment. BJOG 2014;121 Suppl 1:49-56. https://doi.org/10.1111/1471-0528.12659.

52. Miller A, Riehle-Colarusso T, Siffel C, Frías JL, Correa A. Maternal age and prevalence of isolated congenital heart defects in an urban area of the United States. Am J Med Genet A 2011;155A(9):2137-2145. https://doi.org/ 10.1002/ajmg.a.34130.

53. Forrester MB, Merz RD. Descriptive epidemiology of selected congenital heart defects, Hawaii, 1986-1999. Paediatr Perinat Epidemiol 2004;18(6):415424. https://doi.org/10.1111/j.1365-3016.2004.00594.x.

54. Cedergren MI, Selbing AJ, Källén BA. Risk factors for cardiovascular malformation--a study based on prospectively collected data. Scand J Work Environ Health 2002;28(1):12-17. doi:10.5271/sjweh.641.

55. Long J, Ramadhani T, Mitchell LE. Epidemiology of nonsyndromic conotruncal heart defects in Texas, 1999-2004. Birth Defects Res A Clin Mol Teratol 2010;88(11):971-979. https://doi.org/10.1002/bdra.20724

56. Best KE, Rankin J. Is advanced maternal age a risk factor for congenital heart disease? Birth Defects Res A Clin Mol Teratol 2016;106(6):461-467. https:// doi.org/10.1002/bdra.23507.

57. Marceau K, McMaster MT, Smith TF, Daams JG, van Beijsterveldt CE, Boomsma DI, Knopik VS. The prenatal environment in twin studies: a review on Chorionicity. Behav Genet 2016;46(3):286-303. https://doi.org/10.1007/ s10519-016-9782-6.

58. Weiner E, Barber E, Feldstein O, Dekalo A, Schreiber L, Bar J, Kovo M. Placental histopathology differences and neonatal outcome in DichorionicDiamniotic as compared to Monochorionic-Diamniotic twin pregnancies. Reprod Sci 2018;25(7):1067-1072. https://doi.org/10. 1177\%2F1933719117732163.

59. Hermel DJ, Chiu V, Hermel MH, Tulpule A, Akhtari M. Cardiac birth defects in a twin infant born to a woman with chronic myeloid leukemia on dasatinib. J Oncol Pharm Pract 2019;25(3):699-702. https://doi.org/10.1177/ 1078155217745710

\section{Publisher's Note}

Springer Nature remains neutral with regard to jurisdictional claims in published maps and institutional affiliations. 